Atmos. Chem. Phys., 17, 11025-11040, 2017

https://doi.org/10.5194/acp-17-11025-2017

(c) Author(s) 2017. This work is distributed under

the Creative Commons Attribution 3.0 License.

\title{
Exploring sources of biogenic secondary organic aerosol compounds using chemical analysis and the FLEXPART model
}

\author{
Johan Martinsson ${ }^{1,2}$, Guillaume Monteil ${ }^{3}$, Moa K. Sporre ${ }^{4}$, Anne Maria Kaldal Hansen ${ }^{5}$, Adam Kristensson ${ }^{1}$, \\ Kristina Eriksson Stenström ${ }^{1}$, Erik Swietlicki ${ }^{1}$, and Marianne Glasius ${ }^{5}$ \\ ${ }^{1}$ Division of Nuclear Physics, Lund University, P.O. Box 118, 22100, Lund, Sweden \\ ${ }^{2}$ Centre for Environmental and Climate Research, Lund University, Ecology Building, 22362, Lund, Sweden \\ ${ }^{3}$ Department of Physical Geography, Lund University, Lund, P.O. Box 118, 22100, Lund, Sweden \\ ${ }^{4}$ Department of Geosciences, University of Oslo, P.O. Box 1022, Blindern, 0315, Oslo, Norway \\ ${ }^{5}$ Department of Chemistry and iNANO, Aarhus University, Langelandsgade 140, 8000, Aarhus C, Denmark \\ Correspondence to: Johan Martinsson (johan.martinsson@ nuclear.lu.se)
}

Received: 1 February 2017 - Discussion started: 8 February 2017

Revised: 28 June 2017 - Accepted: 24 July 2017 - Published: 18 September 2017

\begin{abstract}
Molecular tracers in secondary organic aerosols (SOAs) can provide information on origin of SOA, as well as regional scale processes involved in their formation. In this study 9 carboxylic acids, 11 organosulfates (OSs) and 2 nitrooxy organosulfates (NOSs) were determined in daily aerosol particle filter samples from Vavihill measurement station in southern Sweden during June and July 2012. Several of the observed compounds are photo-oxidation products from biogenic volatile organic compounds (BVOCs). Highest average mass concentrations were observed for carboxylic acids derived from fatty acids and monoterpenes (12.3 \pm 15.6 and $13.8 \pm 11.6 \mathrm{ng} \mathrm{m}^{-3}$, respectively). The FLEXPART model was used to link nine specific surface types to single measured compounds. It was found that the surface category "sea and ocean" was dominating the air mass exposure (56\%) but contributed to low mass concentration of observed chemical compounds. A principal component (PC) analysis identified four components, where the one with highest explanatory power $(49 \%)$ displayed clear impact of coniferous forest on measured mass concentration of a majority of the compounds. The three remaining PCs were more difficult to interpret, although azelaic, suberic, and pimelic acid were closely related to each other but not to any clear surface category. Hence, future studies should aim to deduce the biogenic sources and surface category of these compounds. This study bridges micro-level chemical speciation to air mass surface exposure at the macro level.
\end{abstract}

\section{Introduction}

Carbonaceous aerosols are abundant in ambient air around the world and account for $40 \%$ of the European $\mathrm{PM}_{2.5}$ mass (Putaud et al., 2010). The carbonaceous aerosol fraction has severe effects on human health as well as a profound effect on the Earth climate system (Dockery et al., 1993; Pope et al., 1995). During summer, carbonaceous aerosols are mainly of biogenic origin, emitted either through primary emissions or gas-phase oxidation products from biogenic volatile organic compounds (BVOCs) (Genberg et al., 2011; Yttri et al., 2011). BVOCs are primarily emitted from plants as a tool for communication and to handle biotic and abiotic stress (Laothawornkitkul et al., 2009; Monson et al., 2013; Penuelas and Llusia, 2003; Sharkey et al., 2008). The emissions of BVOCs tend to increase with increasing temperature and photosynthetically active radiation (PAR) (Guenther et al., 1995, 1993; Hakola et al., 2003). Global BVOC emissions are dominated by isoprene $\left(\mathrm{C}_{5} \mathrm{H}_{8}\right)$ and monoterpenes $\left(\mathrm{C}_{10} \mathrm{H}_{16}\right)$ (Laothawornkitkul et al., 2009). Isoprene is emitted from a variety of plants, but mainly from deciduous forests and shrubs, which may account for more than $70 \%$ of the emissions (Guenther et al., 2006). Monoterpenes are largely emitted from coniferous trees like pine and spruce, but also from some deciduous trees, such as birch (Mentel et al., 2009). The most abundant monoterpenes in the boreal forests include $\alpha$-pinene, $\beta$-pinene, $\Delta^{3}$-carene and limonene (Hakola et al., 2012; Räisänen et al., 2008). 
Biogenic secondary organic aerosols (BSOAs) are formed by photo-oxidation of BVOCs, a process which tends to lower the saturation vapor pressure of the oxidation products relative to that of the BVOCs, thus forcing the gas-phase products to partition in the aerosol phase. BSOA has been shown to dominate over combustion source aerosols during summer (Genberg et al., 2011; Yttri et al., 2011). Yttri et al. (2011) performed source apportionment at four sites in Scandinavia during August 2009 and found that the biogenic contribution to the carbonaceous aerosol dominated (69-86\%) at all four sites. Genberg et al. (2011) performed a 1-year source apportionment at one site in southern Sweden where they apportioned $80 \%$ of the summertime carbonaceous aerosol to biogenic sources. Gelencser et al. (2007) also reported biogenic source dominance $(63-76 \%)$ of the carbonaceous aerosol at six sites in south-central Europe during summer. Castro et al. (1999) observed a maximum and minimum in SOA in Europe during summer and winter, respectively. The relative SOA contribution was higher in rural forest and ocean measurement sites compared to urban sites (Castro et al., 1999).

BSOA consists of a myriad of organic compounds. Small (carbon number: $\left.\mathrm{C}_{3}-\mathrm{C}_{6}\right)$ and larger $\left(\mathrm{C}_{7}-\mathrm{C}_{9}\right)$ dicarboxylic acids are highly hydrophilic and hygroscopic, which have shown to result in potential strong climate effect due to their cloud condensation properties (Cruz and Pandis, 1998; Kerminen, 2001). Dicarboxylic acid contribution to carbon mass has been estimated to 1-3\% in urban and semi-urban areas and up to $10 \%$ in remote marine areas (Kawamura and Ikushima, 1993; Kawamura and Sakaguchi, 1999). Primary aerosol sources of dicarboxylic acids in atmospheric aerosols include ocean emissions, engine exhausts and biomass burning (Kawamura and Kaplan, 1987; Kundu et al., 2010; Mochida et al., 2003). However, the main source of dicarboxylic acids are oxidation/photo-oxidation processes of VOCs (Zhang et al., 2010). These VOC precursors may originate from both anthropogenic and biogenic sources (Mochida et al., 2003). However, BVOCs constitute more than $50 \%$ of all atmospheric VOCs, which is approximately equal to $1150 \mathrm{Tg}$ carbon $\mathrm{yr}^{-1}$ (Guenther et al., 1995; Hallquist et al., 2009).

Organosulfates (OSs) and nitrooxy organosulfates (NOSs) are low-volatility SOA products that in recent years have gained increased attention due to their potential properties as tracers for atmospheric ageing of aerosols in polluted air masses (Hansen et al., 2015, 2014; Kristensen, 2014; Kristensen and Glasius, 2011; Nguyen et al., 2014). Many of these compounds are formed from isoprene and monoterpene oxidation products that react with sulfuric acid in the aerosol phase (Iinuma et al., 2007; Surratt et al., 2010, 2007b). Since atmospheric sulfuric acid is mainly of anthropogenic origin (Zhang et al., 2009), presence of OSs from biogenic organic precursors thus indicates an effect of anthropogenic influence on BSOA (Hansen et al., 2014). Recently, OSs from anthropogenic organic precursors such as alkanes and poly- cyclic aromatic hydrocarbons (PAHs) have also been discovered (Riva et al., 2016, 2015). Tolocka and Turpin (2012) estimated that OSs could comprise up to $10 \%$ of the total organic aerosol mass in the US.

Many carboxylic acids and OSs originate from biogenic sources, however, the exact vegetation types emitting the precursor are poorly explored (Mochida et al., 2003; Tolocka and Turpin, 2012). Coniferous forests, deciduous forests, arable land, pastures etc. are all examples of potential BVOCs sources. Information on specific land surface type BVOCs and BSOA emissions is potentially crucial if an increased understanding should be reached on how land-use changes will affect organic aerosol levels and composition. Van Pinxteren et al. (2010) demonstrated how air mass exposure to land cover affected the measured size-resolved organic carbon (OC), elemental carbon (EC) and inorganic compounds at a receptor site in Germany by using the HYSPLIT model. Yttri et al. (2011) measured one dicarboxylic acid (pinic acid), four OSs and two NOSs at four locations in Scandinavia and connected this measurement data to the FLEXPART model (Stohl et al., 2005) footprint of specific surface landscape types. They used 13 types of surface landscapes and found that the two NOSs (MW 295 and MW 297, both formed from monoterpenes) correlated with air mass exposure to mixed forest (Yttri et al., 2011).

In this study, a comprehensive measurement campaign was conducted in order to investigate sources and levels of BSOA. Thirty-eight sequential $24 \mathrm{~h}$ filter samples were analysed for 9 species of carboxylic acids, 11 species of OSs and 2 species of NOSs at a rural background station in southern Sweden. FLEXPART model simulations at the time and location of the observations were then used to estimate the potential origin of the aerosols sampled.

\section{Methods}

\subsection{Location and sampling}

The Vavihill measurement station is a rural background station in southern Sweden $\left(56^{\circ} 01^{\prime} \mathrm{N}, 13^{\circ} 09^{\prime} \mathrm{E} ; 172 \mathrm{~m}\right.$ a.s.l. $)$ within ACTRIS (Aerosols, Clouds and Trace gases Research Infrastructure) and EMEP (European Monitoring and Evaluation Programme). The surrounding landscape consists of pastures, mixed forest and arable land. The largest nearby cities are Helsingborg (140 000 inhabitants), Malmö (270000 inhabitants) and Copenhagen (1990000 inhabitants) at a distance of 25,45 and $50 \mathrm{~km}$, respectively. These cities are in the west and southwest direction from the measurement station. Previous observations have shown that air masses from continental Europe are usually more polluted than air masses from the north and westerly direction, i.e. Norwegian Sea and Atlantic Ocean (Kristensson et al., 2008). 
Thirty-eight filter samples of aerosols were collected at the Vavihill field station in southern Sweden from 10 June to 18 July 2012. Aerosols were collected on $150 \mathrm{~mm}$ quartz fibre filters (Advantec) using a high-volume sampler (Digitel, DHA-80) with a $\mathrm{PM}_{1}$ inlet. The filters were heated to $900{ }^{\circ} \mathrm{C}$ for $4 \mathrm{~h}$ prior to sampling, with the purpose of removing adsorbed organic compounds from the filters. The sampling air flow was $530 \mathrm{~L} \mathrm{~min}^{-1}$ and total sampling time per filter was $24 \mathrm{~h}$. Sampled filters were wrapped in aluminium foil and stored at $-18^{\circ} \mathrm{C}$ until extraction.

\subsection{BSOA analysis}

The method for extraction and analysis is based on previous studies (Hansen et al., 2014; Kristensen and Glasius, 2011; Nguyen et al., 2014) and thus only described briefly here. For extraction each filter was placed in a beaker and spiked with $15 \mu \mathrm{L}$ of a $100 \mu \mathrm{g} \mathrm{mL}^{-1}$ recovery standard (camphoric acid). The filter was covered with $90 \%$ acetonitrile with $10 \%$ Milli-Q water and extracted in a cooled ultrasound bath for $30 \mathrm{~min}$. The extract was filtered through a Teflon filter $(0.45 \mu \mathrm{m}$ pore size, Chromafil) and evaporated until dryness using a rotary evaporator. The sample was then redissolved twice in $0.5 \mathrm{~mL} 3 \%$ acetonitrile, $0.1 \%$ acetic acid, and stored in a refrigerator $\left(3-5{ }^{\circ} \mathrm{C}\right)$ until analysis. The samples were analysed with an ultra-high-performance liquid chromatograph (UHPLC, Dionex) coupled to a quadrupole time-of-flight mass spectrometer (q-TOF-MS, Bruker Daltonics) through an electro-spray ionization (ESI) inlet. The UHPLC stationary phase was an Acquity T3 $1.8 \mu \mathrm{m}(2.1 \times$ $100 \mathrm{~mm}$ ) column from Waters, and the mobile phase consisted of eluent A ( $0.1 \%$ acetic acid in Milli-Q water) and eluent B (acetonitrile with $0.1 \%$ acetic acid). The operational eluent flow was $0.3 \mathrm{~mL} \mathrm{~min}^{-1}$ and an $18 \mathrm{~min}$ multistep gradient was applied: from 1 to $10 \mathrm{~min}$ eluent $\mathrm{B}$ increased from 3 to $30 \%$, then eluent B increased to $90 \%$ during $1 \mathrm{~min}$, where it was held for $1 \mathrm{~min}$, before eluent $\mathrm{B}$ was increased further to $95 \%$ (during $0.5 \mathrm{~min}$ ) kept here for $3.5 \mathrm{~min}$ before reduction to $3 \%$ (during $0.5 \mathrm{~min}$ ) for the remaining $0.5 \mathrm{~min}$ of the analysis. The ESI-q-TOF-MS instrument was operated in negative ionization mode with a nebulizer pressure of 3.0 bar and a dry gas flow of $8 \mathrm{~L} \mathrm{~min}^{-1}$. All data were acquired and processed using Bruker Compass software. Analysed dicarboxylic acids are summarized in Table 1 and OSs and NOSs are summarized in Table 2. Authentic standards were used for identification and quantification of all carboxylic acids, while OSs and NOSs were identified based on their MS/MS loss of $\mathrm{HSO}_{4}^{-}(m / z=97)$ and an additional neutral loss of $\mathrm{HNO}_{3}(u=63)$ in the case of NOSs. This work focused on identification of OSs from biogenic organic precursors, since OSs from alkanes and PAHs had not been discovered at the time of the analysis. OSs and NOSs were quantified using surrogate standards of OS 250 derived from $\beta$-pinene (synthesized in-house), octyl sulfate sodium salt ( $\geq 95 \%$ Sigma-Aldrich) or D-mannose-6-sulfate sodium salt ( $\geq 90 \%$ Sigma-Aldrich) based on their retention times in the UHPLC-q-TOF-MS system (Table 2). A linear or quadratic relationship between peak area and concentration was demonstrated for all standards and surrogates, and the correlation coefficients, $R^{2}$, of all calibration curves were better than 0.98 ( $n=7$ data points).

The analytical uncertainty was estimated to be $<20 \%$ for carboxylic acids and $<25 \%$ for OSs and NOSs. The uncertainty of the absolute concentrations of OSs and NOSs are higher than carboxylic acids due to lack of authentic standards.

\subsection{Auxiliary measurements and analysis}

$\mathrm{PM}_{2.5}$ was measured with $1 \mathrm{~h}$ time resolution using a tapered element oscillating microbalance (TEOM, Thermo, 8500 FDMS), and estimated uncertainty was less than $25 \%$. Geographical air mass origin was analysed with the Hybrid Single Particle Lagrangian Integrated Trajectory (HYSPLIT) model (Draxler and Hess, 1998; Stein et al., 2015). Gridded meteorological data from the Center for Environmental Prediction (NCEP) Global Data Assimilation System (GDAS) were used as input by the trajectory model. Back-trajectories were calculated at an hourly frequency $120 \mathrm{~h}$ backward in time and the trajectories started $100 \mathrm{~m}$ above ground at the Vavihill measurement site. For each filter sample, 24 trajectories were used since the sampling time was $24 \mathrm{~h}$.

\subsection{Source apportionment}

The concentration and chemical composition of an aerosol sample depends on the trajectory of the sampled air mass in the days preceding the observation (whether or not it comes in contact with a source of aerosols or of aerosol precursors), but also on other meteorological factors such as the temperature and the amount of solar radiation (which control the chemical reactions that lead to production, destruction and transformation of aerosols), and the occurrence of precipitation, which can lead to a rapid scavenging of aerosol particles.

A formal source apportionment would typically involve using a complex chemistry-transport model, able to account for the most important of these factors, and comparing this model results with the observations to validate or refute hypotheses on the origin of the aerosols. The size of our observation dataset is unfortunately too limited for such an exercise to provide meaningful results. Instead, we opted for a much simpler approach: we first used the FLEXPART model to compute back-trajectories corresponding to the air masses sampled. We then used these back-trajectories to estimate the exposure of each sample to various land surface types. Finally, we analysed the relations between the surface type exposures and the aerosols chemical composition of the samples to deduce information about the origin of the sampled aerosols. 
Table 1. Analysed organic acids in the Vavihill aerosol samples. Measured $m / z$, molecular formula, possible molecular structure, suggested precursor and assigned precursor class.

\begin{tabular}{|c|c|c|c|c|c|}
\hline Precursor class & Name & Measured $m / z$ & $\begin{array}{l}\text { Molecular } \\
\text { formula }\end{array}$ & $\begin{array}{l}\text { Possible } \\
\text { structure }\end{array}$ & $\begin{array}{l}\text { Suggested } \\
\text { precursor }\end{array}$ \\
\hline \multirow{2}{*}{ Anthropogenic } & Adipic acid & 145.050 & $\mathrm{C}_{6} \mathrm{H}_{10} \mathrm{O}_{4}$ & & Cyclohexene $^{\mathrm{a}}$ \\
\hline & Pimelic acid & 159.065 & $\mathrm{C}_{7} \mathrm{H}_{12} \mathrm{O}_{4}$ & & Cycloheptene $^{\mathrm{a}}$ \\
\hline \multirow{3}{*}{ Fatty-acid-derived } & Suberic acid & 173.081 & $\mathrm{C}_{8} \mathrm{H}_{14} \mathrm{O}_{4}$ & & Unsaturated fatty acid ${ }^{b, c}$ \\
\hline & Azelaic acid & 187.097 & $\mathrm{C}_{9} \mathrm{H}_{16} \mathrm{O}_{4}$ & & Unsaturated fatty acid $\mathrm{b}, \mathrm{c}$ \\
\hline & Pinic acid & 185.081 & $\mathrm{C}_{9} \mathrm{H}_{14} \mathrm{O}_{4}$ & & $\alpha-/ \beta$-Pinene $\mathrm{d}^{\mathrm{d}, \mathrm{e}}$ \\
\hline \multirow[t]{2}{*}{ First-generation monoterpene } & Pinonic acid & 183.102 & $\mathrm{C}_{10} \mathrm{H}_{16} \mathrm{O}_{3}$ & & $\alpha-/ \beta$-Pinene $\mathrm{d}^{\mathrm{d}, \mathrm{e}}$ \\
\hline & Terpenylic acid & 171.065 & $\mathrm{C}_{8} \mathrm{H}_{12} \mathrm{O}_{4}$ & & $\alpha$-Pinene ${ }^{\mathrm{f}}$ \\
\hline \multirow[t]{2}{*}{$\begin{array}{l}\text { Second-generation } \\
\text { monoterpene }\end{array}$} & $\begin{array}{l}\text { 3-Methyl-1,2,3-butane-tricarboxylic } \\
\text { acid (MBTCA) }\end{array}$ & 203.055 & $\mathrm{C}_{8} \mathrm{H}_{12} \mathrm{O}_{6}$ & & $\alpha$-Pinene ${ }^{\mathrm{d}}$ \\
\hline & Diaterpenylic acid acetate (DTAA) & 231.086 & $\mathrm{C}_{10} \mathrm{H}_{16} \mathrm{O}_{6}$ & II & $\alpha$-Pinene $^{\mathrm{f}}$ \\
\hline
\end{tabular}

${ }^{a}$ Hatakeyama et al. (1987). ${ }^{\mathrm{b}}$ Stephanou and Stratigakis (1993). ${ }^{\mathrm{c}}$ Kawamura and Gagosian (1987). ${ }^{\mathrm{d}}$ Szmigielski et al. (2007). ${ }^{\mathrm{e}}$ Ma et al. (2007). ${ }^{\mathrm{f}}$ Claeys et al. (2009).

\subsubsection{Footprint computations}

For each observation, 7-day footprints (i.e. sensitivity of the observations to surface processes) are computed, using the FLEXPART Lagrangian particle dispersion model in its version 10.0 (Seibert and Frank, 2004; Stohl et al., 2005). The response functions are computed hourly, 7 days backward, on a $0.2^{\circ} \times 0.2^{\circ}$ grid ranging from 30 to $65^{\circ} \mathrm{N}$ and from $2^{\circ} \mathrm{W}$ to $32^{\circ} \mathrm{E}$. Only one (surface) layer is used, ranging from the surface to $400 \mathrm{~m}$ altitude. This choice of a relatively thick surface layer is a compromise between the necessity to account for a maximum of the aerosol production, which does not occurs only at the earth (or canopy) surface, and the fact that the higher the altitude, the more mixed the air. This setting also means that we do not compute the sensitivity of the observations to aerosol production/destruction above $400 \mathrm{~m}$. Even though aerosol formation occurs throughout the whole troposphere (de Reus et al., 2000), it would be impossible, with our simple model approach, to distinguish in situ aerosol production from long-range transport.

Each footprint was computed based on the dispersion 7 days backward in time of 100000 particles. An average particle size of $250 \mathrm{~nm}$ was used, with a size distribution parameter ("dsigma") of 12.5 , meaning that $68 \%$ of the total particles mass is in a $250 / 12.5$ to $250 \times 12.5 \mathrm{~nm}$ range. Previous particle-size measurements at Vavihill measurement station have shown a distribution around a mean of $\sim 100 \mathrm{~nm}$ (Kristensson et al., 2008). The particles density was set to $1500 \mathrm{~kg} \mathrm{~m}^{-3}$. We briefly discuss the impact of these selected parameters in Sect. 3.4. FLEXPART configuration files are provided in the Supplement. 
Table 2. Analysed organosulfates (OSs) and nitrooxy organosulfates (NOSs) in the Vavihill aerosol samples. Measured $m / z$, molecular formula, possible molecular structure, suggested precursor and assigned precursor class.

\begin{tabular}{|c|c|c|c|c|c|}
\hline Precursor class & Name & Measured $m / z$ & $\begin{array}{l}\text { Molecular } \\
\text { formula }\end{array}$ & $\begin{array}{l}\text { Possible } \\
\text { structure }\end{array}$ & $\begin{array}{l}\text { Suggested } \\
\text { precursor }\end{array}$ \\
\hline \multirow{5}{*}{$\begin{array}{l}\text { Isoprene/ } \\
\text { anthropogenic }\end{array}$} & OS $140^{1}$ & 138.970 & $\mathrm{C}_{2} \mathrm{H}_{4} \mathrm{O}_{5} \mathrm{~S}$ & $\mathrm{OSO}_{3} \mathrm{H}$ & Glycolaldehyde $^{\mathrm{a}}$ \\
\hline & OS $154^{1}$ & 152.985 & $\mathrm{C}_{3} \mathrm{H}_{6} \mathrm{O}_{5} \mathrm{~S}$ & & $\begin{array}{l}\text { Hydroxyacetone }^{\mathrm{a}} / \text { methacrolein }^{\mathrm{b}} / \\
\text { methyl vinyl ketone }\end{array}$ \\
\hline & OS $156^{1}$ & 154.961 & $\mathrm{C}_{2} \mathrm{H}_{4} \mathrm{O}_{6} \mathrm{~S}$ & & Glycolic acid $^{\mathrm{c}, \mathrm{d}} /$ methyl vinyl ketone $\mathrm{b}^{\mathrm{b}}$ \\
\hline & OS $170^{1}$ & 168.979 & $\mathrm{C}_{3} \mathrm{H}_{6} \mathrm{O}_{6} \mathrm{~S}$ & & Methylglycolic acid ${ }^{c, d}$ \\
\hline & OS $200^{1}$ & 198.991 & $\mathrm{C}_{4} \mathrm{H}_{8} \mathrm{O}_{7} \mathrm{~S}$ & & 2-Methylglyceric acid ${ }^{\mathrm{a}, \mathrm{e}}$ \\
\hline \multirow{4}{*}{ Isoprene } & OS $212^{1}$ & 210.991 & $\mathrm{C}_{5} \mathrm{H}_{8} \mathrm{O}_{7} \mathrm{~S}$ & $\mathrm{OH}$ & Isoprene $\mathrm{f}^{\mathrm{f} g}$ \\
\hline & OS $214^{1}$ & 213.007 & $\mathrm{C}_{5} \mathrm{H}_{10} \mathrm{O}_{7} \mathrm{~S}$ & More isomers & Isoprene $^{\mathrm{f}}$ \\
\hline & OS $216^{1}$ & 215.021 & $\mathrm{C}_{5} \mathrm{H}_{12} \mathrm{O}_{7} \mathrm{~S}$ & & $\mathrm{C}_{5}$-epoxydiols from isoprene (IEPOX) ${ }^{\mathrm{h}}$ \\
\hline & OS $250^{2}$ & 249.080 & $\mathrm{C}_{10} \mathrm{H}_{18} \mathrm{O}_{5} \mathrm{~S}$ & More isomers & $\begin{array}{l}\alpha \text {-/ } \beta \text {-Pinene and } \\
\text { limonene }^{\mathrm{f}}\end{array}$ \\
\hline \multirow[t]{2}{*}{ Monoterpene } & OS $268^{2}$ & 267.053 & $\mathrm{C}_{9} \mathrm{H}_{16} \mathrm{O}_{7} \mathrm{~S}$ & & Limonene $^{f}$ \\
\hline & OS $280^{2}$ & 279.054 & $\mathrm{C}_{10} \mathrm{H}_{16} \mathrm{O}_{7} \mathrm{~S}$ & & $\alpha-/ \beta$-Pinene ${ }^{\mathrm{f}}$ \\
\hline \multirow{2}{*}{ Monoterpene NOS } & $\operatorname{NOS} 295^{3}$ & 294.062 & $\mathrm{C}_{10} \mathrm{H}_{17} \mathrm{O}_{7} \mathrm{NS}$ & More isomers & $\begin{array}{l}\alpha-/ \beta \text {-Pinene, } \\
\text { Limonene }^{\mathrm{a}, \mathrm{f}}\end{array}$ \\
\hline & $\operatorname{NOS} 297^{2}$ & 296.044 & $\mathrm{C}_{9} \mathrm{H}_{15} \mathrm{O}_{8} \mathrm{NS}$ & More isomers & Limonene ${ }^{f}$ \\
\hline
\end{tabular}

${ }^{a}$ Surratt et al. (2007a). ${ }^{b}$ Schindelka et al. (2013). ${ }^{\mathrm{c}}$ Olson et al. (2011). ${ }^{\mathrm{d}}$ Shalamzari et al. (2013). ${ }^{\mathrm{e}}$ Gomez-Gonzalez et al. (2008). ${ }^{\mathrm{f}}$ Surratt et al. (2008). ${ }^{\mathrm{g}}$ Hettiyadura et al. (2015). ${ }^{\mathrm{h}}$ Surratt et al. (2010). The OSs and NOSs were quantified with D-mannose 6-sulfate (1), $\beta$-pinene OS 250 (2) or octyl sulfate (3). 


\subsubsection{Land surface type exposures}

To compute the exposure of each sample to different land surface types, we coupled the information from the footprints to the CORINE 2012 land cover map (Copernicus, 2012). CORINE 2012 is a high-resolution $(250 \mathrm{~m} \times 250 \mathrm{~m})$ map of the land surface types in the European Union (44 land surface categories, to which we added a "sea and ocean" category). The exposure $E_{i}$ of one observation to the land type $i$ is given by $E_{i}=\sum_{j} f_{j}^{i} R_{j}$, where $j$ is one pixel of the domain, $f_{j}^{i}$ is the fraction of the land surface type $i$ in that pixel, and $R_{j}$ is the sensitivity of the observation to that pixel (i.e. the value of the footprint at that location), divided by the height of the surface layer $(400 \mathrm{~m})$ and by the size of the grid cell.

It is important to remember that since aerosol formation/destruction along the particles trajectories is not accounted for in the FLEXPART simulations (except for deposition processes), these land surface exposures are not a proper source apportionment, only a tool to interpret the observations.

\subsubsection{Principal component analysis (PCA)}

In order to deduce potential sources of measured BSOA compounds a PCA was performed on measured chemical compounds together with air mass exposure to the landscape surface types derived from the FLEXPART model. The principle of PCA is that if measured parameters from the same source are strongly correlated they are treated as one principal component (PC), i.e. PCA identifies variables that have a prominent role by analysis of correlation and variance. PCA has been an extensively used tool in order to reduce the complexity of atmospheric data and has been applied in several studies on aerosol chemical composition (Almeida et al., 2006; Chan and Mozurkewich, 2007; Ito et al., 2004; Nyanganyura et al., 2007; van Pinxteren et al., 2010, 2014; Viana et al., 2006; Wehner and Wiedensohler, 2003). PCA with VARIMAX rotation was performed by using the software SPSS (version 23, IBM). VARIMAX rotation was chosen due to its property of producing uncorrelated PCs, which aids interpretation of the data. In PCA, it is of good practice to transform all variables into a standardized format (i.e. $Z$ score); however, the PCA solution from the standardized variables did not differ from the unstandardized one. Hence, unstandardized variables were used in the analysis. Extracted factors were varied from 2 to 6 in order to achieve the best logical and physical interpretation of the derived factors. The most interpretable result was found using four extracted factors.
Table 3. Ranges of concentrations, means and standard deviation (SD) of the analysed compounds in aerosol samples collected at the Vavihill measurement station 10 June to 18 July 2012.

\begin{tabular}{lrrrrr}
\hline Compound & $\mathrm{N}$ & Minimum & Maximum & Mean & $\pm \mathrm{SD}$ \\
\cline { 3 - 6 } & & \multicolumn{5}{c}{$\left(\mathrm{ng} \mathrm{m}^{-3}\right)$} \\
\hline Adipic acid & 36 & 0.03 & 19.27 & 1.76 & 3.87 \\
Pimelic acid & 36 & 0.02 & 1.21 & 0.38 & 0.28 \\
Suberic acid & 31 & 0.05 & 9.03 & 2.45 & 2.42 \\
Azelaic acid & 35 & 0.03 & 55.27 & 10.52 & 13.83 \\
Pinic acid & 38 & 0.28 & 4.71 & 1.31 & 1.04 \\
Pinonic acid & 38 & 0.82 & 10.66 & 2.89 & 2.00 \\
Terpenylic acid & 38 & 0.72 & 8.86 & 2.57 & 1.87 \\
DTAA & 38 & 0.04 & 5.67 & 0.84 & 1.23 \\
MBTCA & 38 & 0.38 & 29.42 & 6.18 & 7.00 \\
OS 140 & 38 & 0.02 & 0.28 & 0.11 & 0.07 \\
OS 154 & 38 & 0.15 & 2.95 & 0.76 & 0.64 \\
OS 156 & 32 & 0.02 & 2.35 & 0.65 & 0.61 \\
OS 170 & 38 & 0.08 & 0.78 & 0.33 & 0.17 \\
OS 200 & 38 & 0.06 & 2.02 & 0.41 & 0.40 \\
OS 212 & 38 & 0.16 & 4.63 & 0.91 & 0.95 \\
OS 214 & 38 & 0.06 & 3.08 & 0.50 & 0.58 \\
OS 216 & 38 & 0.06 & 5.83 & 0.63 & 1.07 \\
OS 250 & 38 & 0.02 & 3.48 & 0.51 & 0.64 \\
OS 268 & 38 & 0.01 & 0.48 & 0.13 & 0.12 \\
OS 280 & 32 & 0.01 & 0.70 & 0.09 & 0.17 \\
NOS 295 & 38 & 0.02 & 0.53 & 0.12 & 0.11 \\
NOS 297 & 37 & 0.01 & 0.18 & 0.05 & 0.03 \\
\hline
\end{tabular}

\section{Results and discussion}

\subsection{Variations and features in BSOA compounds}

A total of 9 organic acids, 11 OSs and 2 NOSs of anthropogenic and biogenic origin were determined in the samples (Tables 1 and 2). All organic acids were quantified with authentic standards, whereas the other compounds were quantified with surrogates (see experimental section). On average, the total mass of the organic chemical species from filters contributed to $0.3 \%$ ( $\pm 0.2 \%$, standard deviation) to $\mathrm{PM}_{2.5}$. However, it is worth noting that the particles were sampled through a $\mathrm{PM}_{1}$ inlet, which may have excluded a considerable portion of the mass collected on filters compared to the $\mathrm{PM}_{2.5}$ mass measured by the TEOM. On the other hand, it has been shown that $\mathrm{PM}_{1}$ can comprise up to $90 \%$ of $\mathrm{PM}_{2.5}$ in rural locations during summertime (Gomiscek et al., 2004). Since no gravimetric analysis of filters was performed, no information on the total mass loading of $\mathrm{PM}_{1}$ is available.

In Table 3 and Fig. 1a concentrations of observed compounds during the sampling period are given. The compounds have been merged into groups based on their likely precursors in Fig. 1a (see Tables 1 and 2). It should be noted that pimelic acid, in Table 1 listed as having cycloheptene as a suggested precursor (i.e. to be of anthropogenic origin), can also be synthesized from salicylic acid 


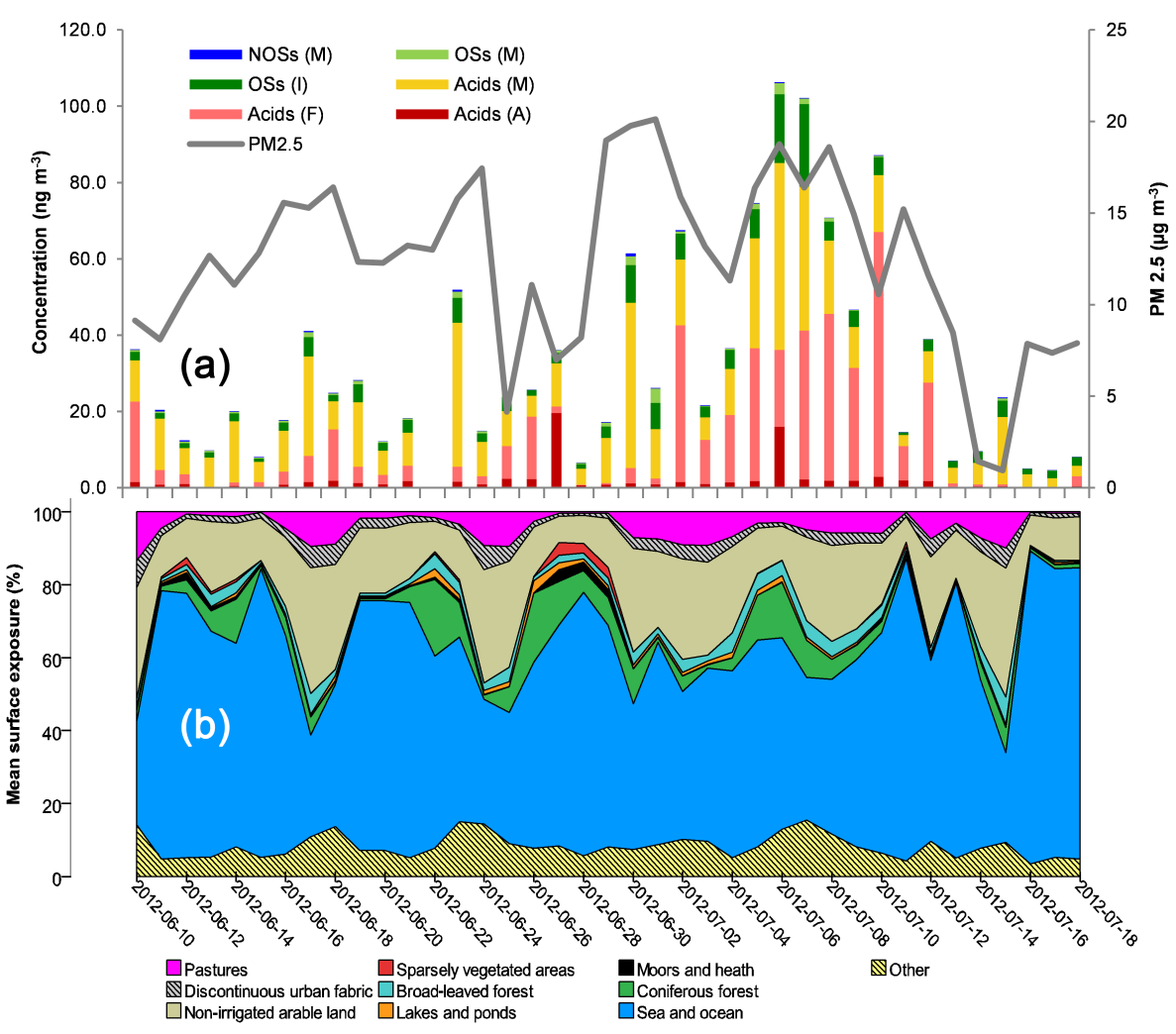

Figure 1. (a) Total concentration of all measured carboxylic acids, organosulfates (OSs) and nitrooxy organosulfates (NOSs) in PM 1 collected at the Vavihill measurement station. The thick grey line displays the $\mathrm{PM}_{2.5}$ concentration. Capital letters in parentheses in the legend are the precursor class given in Tables 1 and 2. A: anthropogenic; F: fatty acid; I: isoprene; and M: monoterpenes. (b) FLEXPART generated mean exposure from the nine mean largest surface categories. The exposure is a mean of 3-, 5- and 7-day back-trajectories. The category "Other" represents the remaining 34 surface categories. More detailed information on the surface categories can be found in the Supplement.

(Müller, 1931), which is a compound naturally found in plants. Hence, whether the main formation route of pimelic acid is anthropogenic or natural is unclear. On the other hand, adipic acid is rarely found naturally and is originally synthesized from benzene (Tuttle Musser, 2000). Table 3 summarizes concentration ranges, means and standard deviations (SDs) for individual dicarboxylic acids, OSs and NOSs. In general the organic acids from monoterpenes and fatty acids dominate the total concentration over the entire period, where the concentration of acids from monoterpenes range from 1.7 to $49.0 \mathrm{ng} \mathrm{m}^{-3}$ and the concentration of organic acids from fatty acids range from 0.03 to $64.1 \mathrm{ng} \mathrm{m}^{-3}$. The concentration of isoprene-derived OSs ranges from 0.34 to $21.6 \mathrm{ng} \mathrm{m}^{-3}$ over the sampling period and dominates over the monoterpene-derived OSs. This pattern has also been observed in other studies in the Nordic countries (Yttri et al., 2011), and is in line with high emissions of isoprene during summer. The NOSs are low in average concentration $\left(\operatorname{NOS} 295=0.12 \pm 0.11 \mathrm{ng} \mathrm{m}^{-3}\right.$, NOS $297=0.05 \pm$ $0.03 \mathrm{ng} \mathrm{m}^{-3}$ ), and are lower than the observed mean concentration by Yttri et al. (2011) from the summer of 2011 (NOS $295=0.74 \mathrm{ng} \mathrm{m}^{-3}$, NOS $297=1.2 \mathrm{ng} \mathrm{m}^{-3}$ ). This could be due to differences in aerosol sources and surrogate standards for quantification between the two studies.

The fatty-acid-derived azelaic acid was found to be the most abundant dicarboxylic acid with a concentration range from 0.03 to $55.3 \mathrm{ng} \mathrm{m}^{-3}$ (mean $=10.5 \pm 13.8 \mathrm{ng} \mathrm{m}^{-3}$ ). Hyder et al. (2012), who measured nine dicarboxylic acids in aerosol samples obtained at the Vavihill measurement station 2008-2009, also found azelaic acid to be the most prominent with peak concentration during summer $\left(16.2 \mathrm{ng} \mathrm{m}^{-3}\right)$. The concentration of the anthropogenic acids is low (mean $\approx 2 \mathrm{ng} \mathrm{m}^{-3}$ ) except during 27 June and 6 July, when the concentration reaches 19.6 and $16.0 \mathrm{ng} \mathrm{m}^{-3}$, respectively. The spike in concentration of anthropogenic acids during these 2 days is caused by an increase in the concentration of adipic acid.

Correlations between the different compounds was investigated by Pearson correlation. All Pearson $r$ coefficients are given in Table 4. In general, the biogenic compounds (derived from isoprene and monoterpenes) correlated well $(r \geq 0.8)$ with each other. The only exception was OS 250, which showed low to medium correlation with the other compounds. 


\begin{tabular}{|c|c|}
\hline 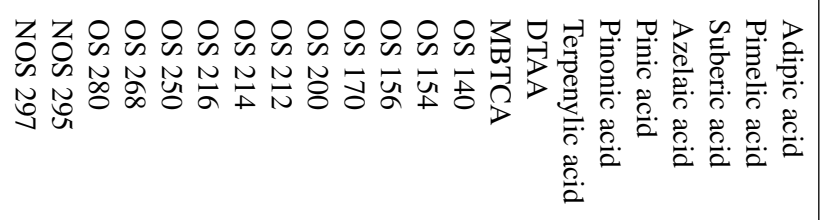 & \\
\hline 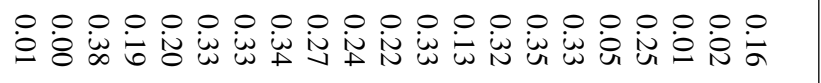 & Adipic acid \\
\hline 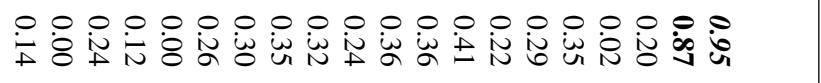 & Pimelic acid \\
\hline 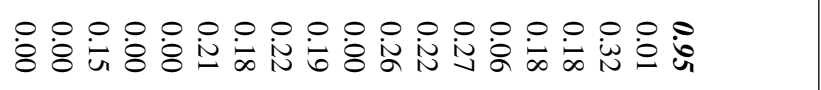 & Suberic acid \\
\hline 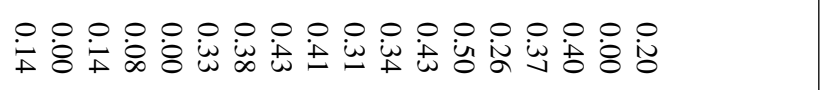 & Azelaic acid \\
\hline 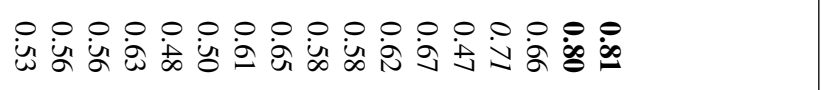 & Pinic acid \\
\hline 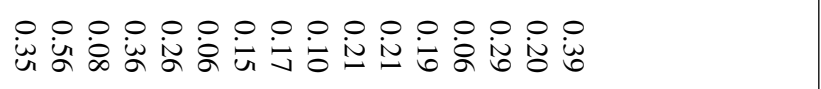 & Pinonic acid \\
\hline 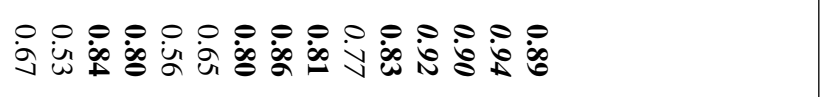 & Terpenylic acid \\
\hline 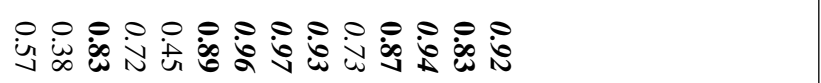 & DTAA \\
\hline 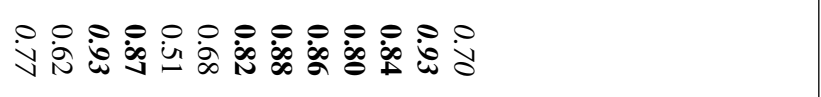 & MBTCA \\
\hline 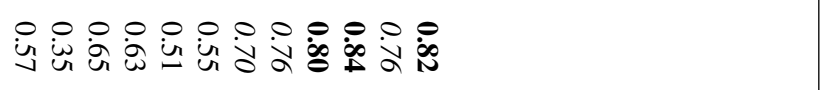 & OS 140 \\
\hline 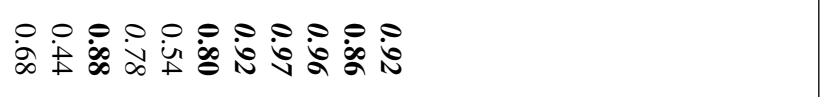 & OS 154 \\
\hline 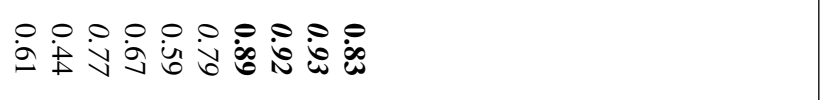 & OS 156 \\
\hline 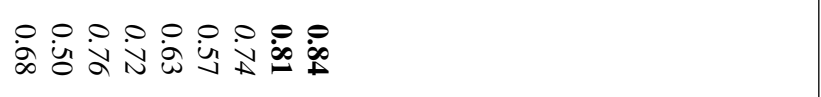 & OS 170 \\
\hline 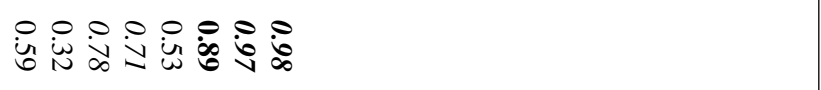 & OS 200 \\
\hline 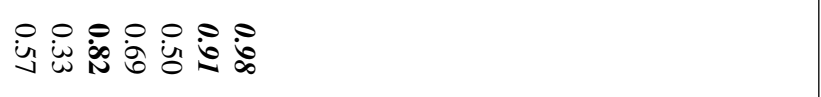 & OS 212 \\
\hline 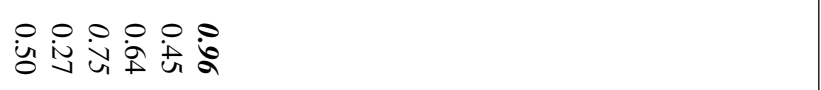 & OS 214 \\
\hline 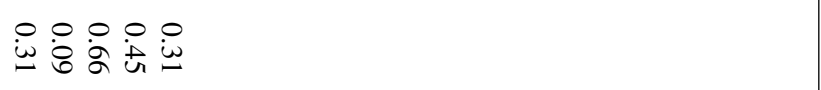 & OS 216 \\
\hline 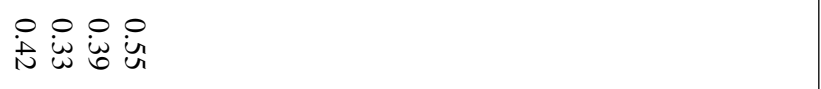 & OS 250 \\
\hline$\stackrel{\circ}{\circ} \stackrel{0}{\partial}$ & OS 268 \\
\hline$\stackrel{\circ}{\partial} \dot{\leftrightarrow}_{u}$ & OS 280 \\
\hline$\underset{\infty}{\infty}$ & $\begin{array}{l}\text { NOS } 295 \\
\text { NOS } 297\end{array}$ \\
\hline
\end{tabular}


Table 5. Ranges, means and standard deviations (SD) of the FLEXPART surface type exposure of incoming air masses during 10 June to 18 July 2012.

\begin{tabular}{lcrrrr}
\hline Surface type & $\mathrm{N}$ & Minimum & Maximum & Mean & \pm SD \\
\cline { 3 - 6 } & & 0 & 13 & 4.4 & 3.6 \\
& 38 & & 7 & 2.6 & 1.7 \\
\hline Pasture & 38 & 1 & 35 & 18.8 & 8.3 \\
Discontinuous urban fabric & 3 & 3 & 0.4 & 0.9 \\
Non-irrigated arable land & 38 & 0 & 8 & 2.6 & 1.7 \\
Sparsely vegetated areas & 38 & 0 & 3 & 0.9 & 0.6 \\
Broad-leaved forest & 38 & 0 & 3 & 0.5 & 0.7 \\
Lakes and ponds & 38 & 0 & 22 & 5.5 & 5.2 \\
Moors and heath & 38 & 0 & 86 & 56.0 & 16.3 \\
Coniferous forest & 38 & 34.6 & 15 & 8.3 & 3.2 \\
Sea and ocean & 38 & 3 & & & \\
Other & 38 & & & \\
\hline
\end{tabular}

Table 6. Correlation matrix displaying the Pearson product-moment coefficient $(r)$ for surface types. Typefaces represent degree of correlation: italic: | $0.7-0.8$ |; bold: | 0.8-0.9|; bolditalic: | 0.9-1.0|.

\begin{tabular}{|c|c|c|c|c|c|c|c|c|c|c|}
\hline & Pasture & $\begin{array}{l}\text { Discontinuous } \\
\text { urban fabric }\end{array}$ & $\begin{array}{l}\text { Non-irrigated } \\
\text { arable land }\end{array}$ & $\begin{array}{r}\text { Sparsely } \\
\text { vegetated } \\
\text { areas }\end{array}$ & $\begin{array}{l}\text { Broad- } \\
\text { leaved } \\
\text { forest }\end{array}$ & $\begin{array}{r}\text { Lakes } \\
\text { and } \\
\text { ponds }\end{array}$ & $\begin{array}{r}\text { Moors } \\
\text { and } \\
\text { heath }\end{array}$ & $\begin{array}{r}\text { Coniferous } \\
\text { forest }\end{array}$ & $\begin{array}{r}\text { Sea } \\
\text { and } \\
\text { ocean }\end{array}$ & Other \\
\hline \multicolumn{11}{|l|}{ Pasture } \\
\hline Discontinuous urban fabric & 0.92 & & & & & & & & & \\
\hline Non-irrigated arable land & 0.89 & 0.9 & & & & & & & & \\
\hline Sparsely vegetated areas & -0.47 & -0.42 & -0.49 & & & & & & & \\
\hline Broad-leaved forest & 0.48 & 0.32 & 0.53 & -0.13 & & & & & & \\
\hline Lakes and ponds & 0 & -0.12 & -0.13 & 0.18 & 0.2 & & & & & \\
\hline Moors and heath & -0.46 & -0.4 & -0.47 & 0.98 & -0.17 & 0.14 & & & & \\
\hline Coniferous forest & -0.17 & -0.31 & -0.22 & 0.23 & 0.43 & -0.8 & 0.17 & & & \\
\hline Sea and ocean & -0.84 & -0.78 & -0.84 & 0.27 & -0.73 & -0.31 & 0.28 & -0.28 & & \\
\hline Other & 0.59 & 0.57 & 0.53 & -0.16 & 0.42 & 0.29 & -0.18 & 0.23 & -0.77 & \\
\hline
\end{tabular}

Three dicarboxylic acids (azelaic, pimelic and suberic acid) correlated well with each other $(r>0.87)$. It is likely that the fatty-acid-derived dicarboxylic acids have a different origin than isoprene- and monoterpene-generated acids, a conclusion that also was reached in a previous study (Hyder et al., 2012). It was expected that adipic acid would show good agreement with pimelic acid since they are both suggested to be of anthropogenic origin. However, this correlation was poor $(r=0.16)$ and is believed to be explained by two strong concentration peaks in adipic acid (27 June and 6 July, Fig. 1a) with no corresponding peak in pimelic acid. Removing these two concentration peaks led to a better agreement between the two acids $(r=0.67)$.

\subsection{Air mass surface exposure}

Figure $1 \mathrm{~b}$ displays the exposures of the samples to the nine largest surface categories as percentage contribution and Tables 5 and 6 present the mean exposures and a correlation matrix for the investigated surface types. These surface categories are explained in more detail in the Supplement. The "sea and ocean" category is dominating the exposure with an average of $56 \%( \pm 16 \%)$. This is hardly surprising since a majority of the incoming air mass is from the westerly region where the North Atlantic Ocean, North Sea and Norwegian Sea are situated. The second most common surface exposure is from "non-irrigated arable land" (mean $=19 \pm 8 \%$ ). This is a common land type in continental Europe which is anticorrelated $(r=-0.84)$ to the "sea and ocean" surface category. The fact that several land-based surface categories anticorrelated to the "sea and ocean" category may be an indicator of the model working properly. The category "other" has a significant contribution to the total exposure (mean $=8 \pm 3 \%$ ), but it groups 34 surface categories and is therefore difficult to interpret beyond the common fact that all these categories are land masses. It is important to remember that these exposures should not be read as a representation of the contribution of the land surface types to the production of the aerosols measured. For that, an estimation of the aerosol production (or transformation) associated with each surface category would be required. However, correlating the land surface exposures to the measured aerosol time series can provide an indication on the origin of the aerosols. 


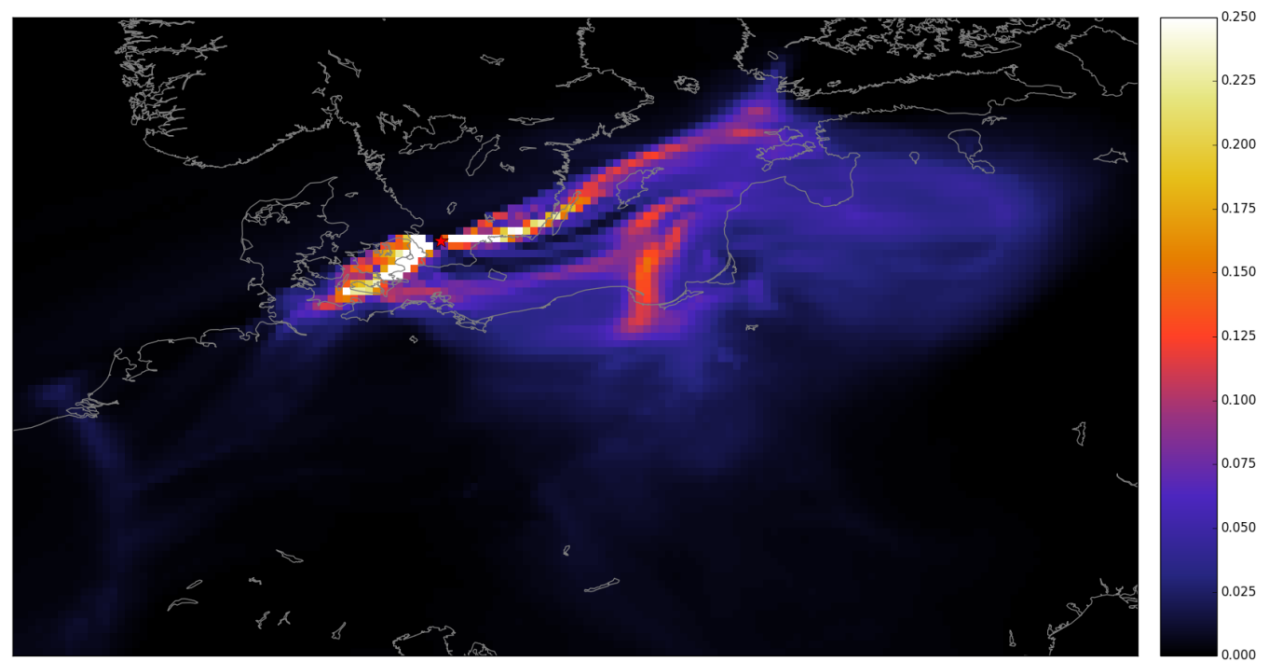

Figure 2. A $120 \mathrm{~h}$ back-trajectory air mass covering the concentration peak dates, 6-8 July. The FLEXPART model back-trajectories are shown in shaded colours. The colour bar displays the FLEXPART footprint, normalized to 1 (the colour range has been limited to 0-0.3 to highlight grid points with low but a non-zero contribution). Together, the grid points with a value larger than 0.1 contribute $17 \%$ of the total sensitivity, while grid boxes with a value larger than 0.01 contribute $81 \%$ of the total sensitivity. The $120 \mathrm{~h}$ back-trajectory was chosen for easier interpretation of the illustration.

During a period of increased concentrations of molecular BSOA compounds (6-8 July) the air mass was more exposed to land surface categories such as "non-irrigated arable land", "coniferous forest", "broad-leaved forest" and "pastures" on the expense of "sea and ocean" (Fig. 1a, b). Further, the category "other" is also increased during this particular period. Within the "other" category, "mixed forest", "complex cultivation patterns", "land principally occupied by agriculture, with significant areas of natural vegetation" and "transitional woodland/shrub" are dominant (more information about the surface categories can be found on the CORINE database website) (EEA, 2016). This particular concentration increase is caused by the fatty-acidderived organic acids, monoterpene-derived organic acids and isoprene-derived OSs (Fig. 1a). The concentration of $\mathrm{PM}_{2.5}$ does not provide any explanation of the cause of the high concentrations, since $\mathrm{PM}_{2.5}$ is in general high during the entire campaign period. Both the HYSPLIT and FLEXPART model revealed that arriving air masses during this period mainly had an origin from continental Europe (Fig. 2). As stated earlier, it has been observed that air masses arriving from this direction usually carry more PM and OSs than from other directions (Nguyen et al., 2014; Kristensson et al., 2008).

The period of increased concentrations of molecular BSOA compounds (6-8 July) is in large contrast to the "clean periods" observed during 12-16 June and 16-18 July (Fig. 1a, b). In particular, the latter period shows very low values of molecular BSOA compounds and a corresponding "sea and ocean" exposure of 79-86\%. Hence, "sea and ocean" exposure does not seem to contribute to the mea- sured mass of molecular BSOA compounds. Similarly, the "non-irrigated arable land" contributes to a significant fraction during 16-18 July (8-12\%) and most probably does not contribute to the mass of measured BSOA species either.

\subsection{Connection between surface type and measured species}

To further investigate the impact of surface types on measured BSOA species a PCA was conducted as described in Sect. 2. A four-PC VARIMAX-rotated solution was chosen. This solution explained $80.3 \%$ of the total variance. Table 7 shows the individual parameter contribution to the respective PC. PC1 accounts for $49.1 \%$ of the total variance and has strong positive contributions from several of the monoterpene-derived dicarboxylic acids and both monoterpene- and isoprene-derived OSs and NOSs. The strongest positive surface category in $\mathrm{PC} 1$ is "coniferous forest", suggesting that the species with a bold number in PC1 within Table 7 are originating, or that their mass concentration have a positive response, from coniferous forest. Coniferous forests are mainly known as large-scale emitters of monoterpenes. Despite this, the PCA illustrates that isoprene oxidation products are positively correlated to this surface category. Steinbrecher et al. (1999) observed negligible emissions of isoprene from common conifers as Scots pine (Pinus sylvestris) and common juniper ( $\mathrm{Ju}$ niperus communis). However, they found significant emissions from Norway spruce (Picea abies) which may explain some of the isoprene-derived compounds in this study. Although the less strong positive contribution of 0.53 , isoprene- 
Table 7. Principal component (PC) loadings. The loadings display the variation (between -1 and 1) explained by the PC. Numbers in bold indicates absolute number $>0.6$. PC1 explained $49.1 \%$, PC2 $14.9 \%$, PC3 $9.3 \%$ and PC4 $6.9 \%$.

\begin{tabular}{|c|c|c|c|c|}
\hline & \multicolumn{4}{|c|}{ Principal component } \\
\hline & 1 & 2 & 3 & 4 \\
\hline Adipic acid & 0.37 & -0.25 & 0.08 & 0.59 \\
\hline Pimelic acid & 0.24 & 0.20 & 0.75 & -0.21 \\
\hline Suberic acid & 0.20 & 0.26 & 0.82 & -0.19 \\
\hline Azelaic acid & 0.21 & 0.39 & 0.74 & -0.17 \\
\hline Pinic acid & 0.70 & -0.04 & -0.25 & 0.14 \\
\hline Pinonic acid & 0.19 & -0.15 & -0.37 & 0.16 \\
\hline Terpenylic acid & 0.88 & 0.29 & -0.11 & 0.04 \\
\hline DTAA & 0.93 & 0.24 & 0.04 & 0.09 \\
\hline MBTCA & 0.89 & 0.28 & -0.26 & -0.02 \\
\hline OS 140 & 0.76 & 0.30 & 0.12 & -0.41 \\
\hline OS 154 & 0.96 & 0.22 & 0.04 & -0.10 \\
\hline OS 156 & 0.93 & 0.06 & 0.04 & -0.14 \\
\hline OS 170 & 0.79 & 0.20 & -0.17 & -0.28 \\
\hline OS 200 & 0.92 & 0.18 & 0.10 & -0.12 \\
\hline OS 212 & 0.95 & 0.18 & 0.13 & -0.01 \\
\hline OS 214 & 0.92 & 0.13 & 0.15 & 0.04 \\
\hline OS 216 & 0.87 & 0.03 & 0.26 & 0.11 \\
\hline OS 250 & 0.48 & -0.06 & -0.38 & -0.06 \\
\hline OS 268 & 0.67 & 0.24 & -0.51 & -0.18 \\
\hline OS 280 & 0.87 & 0.13 & -0.20 & -0.05 \\
\hline NOS 295 & 0.43 & 0.16 & -0.69 & -0.25 \\
\hline NOS 297 & 0.59 & 0.28 & -0.48 & -0.35 \\
\hline Pastures & 0.22 & 0.85 & 0.15 & -0.37 \\
\hline Discontinuous urban fabric & -0.02 & 0.92 & 0.12 & -0.29 \\
\hline Non-irrigated arable land & 0.20 & 0.94 & 0.10 & -0.14 \\
\hline Broad-leaved forest & 0.53 & 0.77 & 0.21 & 0.11 \\
\hline Sparsely vegetated areas & -0.11 & -0.10 & -0.18 & 0.86 \\
\hline Lakes and ponds & 0.76 & 0.34 & 0.02 & 0.42 \\
\hline Moors and heath & -0.16 & -0.04 & -0.23 & 0.85 \\
\hline Coniferous forest & 0.79 & 0.35 & -0.04 & 0.39 \\
\hline Sea and ocean & 0.37 & 0.62 & 0.27 & 0.34 \\
\hline Other & 0.60 & 0.65 & 0.19 & 0.19 \\
\hline
\end{tabular}

emitting "broad-leaved forest" may also have contributed to the above-described pattern in PC1.

PC2 accounts for $14.9 \%$ of the total variation and can roughly be classified as surface categories with low contribution to measured BSOA compounds. Six of the 10 investigated surface categories show strong positive contribution to PC2 while many of the measured compounds show low and in some cases negative contribution to PC2. The observed pattern of high "sea and ocean" and "non-irrigated arable land" exposure when the mass concentration of BSOA compounds was low, further strengthening the explanation of PC2.

PC3 accounts for $9.3 \%$ of the total variance. The main contributors are suberic acid, azelaic acid and pimelic acid. They are all similar in chemical structure, although suberic and azelaic acid probably originate from fatty acids, while pimelic acid likely is of anthropogenic origin (Table 1). Further, azelaic acid has been found to be involved in the trig- gering of the plant immune system (Jung et al., 2009). Hyder et al. (2012), who also found these three acids to be highly correlated in ambient aerosol, inferred that pimelic acid was either produced from the same source as suberic and azelaic acid or that pimelic acid is produced by continued oxidation of suberic and azelaic acid down to acids of lower carbon number. None of the land surface categories displayed a high contribution to PC3: "broad-leaved forest" had the highest contribution of 0.21 , while the other forest category, "conifer forest", had a 1 order of magnitude lower contribution of -0.04 .

PC4 accounted for $6.9 \%$ of the total variance and is harder to interpret than the previous three PCs. The anthropogenically derived adipic acid has a positive PC contribution (0.59) as well as the surface categories "sparsely vegetated areas" $(0.86)$ and "moors and heath" (0.85). The used land cover maps reveals that both "sparsely vegetated areas" and "moors and heath" are mainly found in Norway and northern Sweden, i.e. in the north and northwesterly direction of Vavihill measurement station. The overall interpretation of PC4 is difficult since adipic acid is thought to be of anthropogenic origin but, in this case, seems to correlate with landscape surface types that are sparsely populated and are associated with low human activity (i.e. "sparsely vegetated areas" and "moors and heath").

The complexity in PC4 may be caused by the concentration peaks in adipic acid that occurred 27 June and 6 July (Fig. 1a). During 27 June, the air mass mainly arrived from the Atlantic Ocean and southern Norway, while the air mass during 6 July mainly originated from the Baltic countries and central Europe (partially illustrated in Fig. 2). Removing the two concentration peaks in adipic acid gave a different PCA solution. Adipic acid now falls into the same PCA as pimelic, suberic and azelaic acid with PC contributions of $0.52,0.66,0.70$ and 0.73 , respectively. Further, the new PC solution show that the aforementioned acids are associated with "pastures" (PC contribution $=0.82$ ), "discontinuous urban fabric" (0.84), "non-irrigated arable land" $(0.82)$,"broad-leaved forest" (0.81), "sea and ocean" (0.69) and the "other" category (0.66). Hence, the nature of adipic acid remains unclear since it shows good agreement with the other acids when concentration peaks are removed, implying that adipic is derived from fatty acids or salicylic acid. On the other hand, including the concentration peaks, neither this study nor the study by Hyder et al. (2012) found any strong correlation between adipic and pimelic acid. It can be speculated whether the observed concentration peaks in adipic acid have their explanation in local emission sources of benzene or cyclohexene, followed by a fast oxidation into adipic acid. Future studies should repeat the presented methodology to focus on heavily anthropogenically influenced surface categories (i.e. cities, industries etc.) and their impact on anthropogenic acids and newly discovered anthropogenic OSs (Riva et al., 2016, 2015). 


\subsection{Uncertainties and limits}

In this study, our analysis approach relies on two steps: first the calculation of the exposures, using FLEXPART, and then the estimation of land type contributions using a PCA. Both steps suffer from uncertainties which limit the robustness of our results.

The longer the back-trajectories used in FLEXPART, the larger the error is likely to be. On the other hand, shorter back-trajectories lead to neglecting a larger proportion of "older" aerosols. We tested the impact of the footprint length choice on the exposure time series by repeating the analysis with footprints of 3 and 5 days (instead of 7 days in our default setup). Overall, the exposures are not significantly affected, except for the exposure to the "sea and ocean" surface type during the 8-10 July peak, which show an uncertainty of $6 \%$ (Fig. S1 in the Supplement).

Besides the length of the simulations, a number of FLEXPART settings can impact the results. The size of the aerosols particles has a strong impact on the lifetime of the aerosols in the atmosphere and therefore on the footprints. We have repeated the experiment with mean aerosol sizes of $50 \mathrm{~nm}$ and $1 \mu \mathrm{m}$, and the results of the PCAs remained reasonably similar (Table S1 and S2 in the Supplement). This is mainly because the PCA is sensitive to correlations, and not to absolute values.

The calculation of the observation exposures is based on the assumption that the measured aerosol compositions scale linearly with the aerosol production within the backplume of the observation. This is not the case in reality: processes such as coagulation, nucleation, chemical reactions between aerosols and surrounding reactive gas species, photo-dissociation and wet and dry deposition (removal of aerosols from the atmosphere by the rain and by gravitational settling) alter the aerosol composition and concentration all along the air mass trajectory. Our approach also ignores the influence of aerosol particles (or precursors) older than 7 days on the observations. Accounting adequately for all these processes would require a comprehensive aerosol model, which is out of the scope of this study. This mainly means that our approach cannot be used to quantify the aerosol production associated with, for example, a specific forest type.

The main limit to the PCA is the shortness of the time series. In particular, there is only one strong event during the campaign (6-8 July), which is not enough for drawing strong conclusions. Our study can, however, be regarded as a proof of concept: computing FLEXPART footprints is relatively easy and lightweight, and could be performed routinely. The conclusions of a PCA are likely to be a lot more robust with longer time series with more observations included, and/or multi-site observation campaigns (provided that the footprints of the different sites overlap sufficiently).

\section{Conclusions}

Nine carboxylic acids along with 11 organosulfates (OSs) and 2 nitrooxy organosulfates (NOSs) were analysed from 38 daily aerosol samples sampled at Vavihill measurement station in southern Sweden during June and July 2012. Most of the measured compounds can be considered as photooxidation products from biogenic volatile organic compounds (BVOCs), hence derived from terrestrial plants. The FLEXPART model was used to identify exposure of the aerosol samples to several different surface categories. For easier interpretation, the study was focused on four potential source-specific components using 22 chemical species and the 9 largest surface categories. The "sea and ocean" category was found to dominate the exposure, and other important categories were "non-irrigated arable land" and "pastures". A principal component analysis (PCA) of four principal components (PCs) was used to explore the impact and connection of surface categories on mass concentration of measured biogenic secondary organic aerosol compounds. It was found that coniferous forest had a positive effect on several of the measured monoterpene-derived compounds. The remaining three PCs were harder to interpret; however, future studies should aim to investigate the sources of azelaic, suberic and pimelic acids which dominate in mass concentration but showed no clear correlation to surface categories.

This study demonstrates the interest of using an atmospheric transport model in aerosol source apportionment on specific chemical compounds. With the presented methodology it is possible to connect single chemical tracer compounds to potential local and long-range aerosol sources, i.e. surface categories. More advanced applications may include particle age estimation and its relation to surface categories; this could be achieved by measuring first- and secondgeneration BVOC oxidation products and relating these to its measurable gas-phase precursor.

Data availability. All data are accessible through the Supplement.

\section{The Supplement related to this article is available online at https://doi.org/10.5194/acp-17-11025-2017- supplement.}

Author contributions. JM designed the study, compiled all data, performed the PCA and wrote most of the paper. GM ran the FLEXPART simulations. MKS ran the HYSPLIT simulations. AMKH and MG ran the chemical analysis. AK, ES and KES assisted in the writing process.

Competing interests. The authors declare that they have no conflict of interest. 
Acknowledgements. This work was supported by the Swedish Research Council FORMAS (project 2011-743).

Edited by: Jason Surratt

Reviewed by: three anonymous referees

\section{References}

Almeida, S. M., Pio, C. A., Freitas, M. C., Reis, M. A., and Trancoso, M. A.: Source apportionment of atmospheric urban aerosol based on weekdays/weekend variability: evaluation of road resuspended dust contribution, Atmos. Environ., 40, 2058-2067, https://doi.org/10.1016/j.atmosenv.2005.11.046, 2006.

Castro, L. M., Pio, C. A., Harrison, R. M., and Smith, D. J. T.: Carbonaceous aerosol in urban and rural European atmospheres: estimation of secondary organic carbon concentrations, Atmos. Environ., 33, 2771-2781, https://doi.org/10.1016/S13522310(98)00331-8, 1999.

Chan, T. W. and Mozurkewich, M.: Application of absolute principal component analysis to size distribution data: identification of particle origins, Atmos. Chem. Phys., 7, 887-897, https://doi.org/10.5194/acp-7-887-2007, 2007.

Claeys, M., Iinuma, Y., Szmigielski, R., Surratt, J. D., Blockhuys, F., Van Alsenoy, C., Boge, O., Sierau, B., Gomez-Gonzalez, Y., Vermeylen, R., Van der Veken, P., Shahgholi, M., Chan, A. W. H., Herrmann, H., Seinfeld, J. H., and Maenhaut, W.: Terpenylic Acid and Related Compounds from the Oxidation of alpha-Pinene: Implications for New Particle Formation and Growth above Forests, Environ. Sci. Technol., 43, 6976-6982, https://doi.org/10.1021/es9007596, 2009.

Copernicus: Land Monitoring Services, http://land.copernicus.eu/ pan-european/corine-land-cover/clc-2012 (last acess: 20 October 2016), 2012.

Cruz, C. N. and Pandis, S. N.: The effect of organic coatings on the cloud condensation nuclei activation of inorganic atmospheric aerosol, J. Geophys. Res., 103, 13111-13123, https://doi.org/10.1029/98JD00979, 1998.

de Reus, M., Ström, J., Curtius, J., Pirjola, L., Vignati, E., Arnold, F., Hansson, H. C., Kulmala, M., Lelieveld, J., and Raes, F.: Aerosol production and growth in the upper free troposphere, J. Geophys. Res., 105, 24751-24762, https://doi.org/10.1029/2000JD900382, 2000.

Dockery, D. W., Pope, C. A., Xu, X. P., Spengler, J. D., Ware, J. H., Fay, M. E., Ferris, B. G., and Speizer, F. E.: An Association between Air-Pollution and Mortality in 6 United-States Cities, New Engl. J. Med., 329, 1753-1759, https://doi.org/10.1056/Nejm199312093292401, 1993.

Draxler, R. R. and Hess, G. D.: An overview of the HYSPLIT_4 modelling system for trajectories, dispersion and deposition, Aust. Meteorol. Mag., 47, 295-308, 1998.

EEA: Corine Reports, http://www.eea.europa.eu/publications/ COR0-part2/page001.html (last acess: 20 October 2016), 2016.

Gelencsér, A., May, B., Simpson, D., Sanchez-Ochoa, A., Kasper-Giebl, A., Puxbaum, H., Caseiro, A., Pio, C., and Legrand, M.: Source apportionment of $\mathrm{PM}_{2.5}$ organic aerosol over Europe: Primary/secondary, natural/anthropogenic, and fossil/biogenic origin, J. Geophys. Res., 112, D23S04, https://doi.org/10.1029/2006JD008094, 2007.
Genberg, J., Hyder, M., Stenström, K., Bergström, R., Simpson, D., Fors, E. O., Jönsson, J. A., and Swietlicki, E.: Source apportionment of carbonaceous aerosol in southern Sweden, Atmos. Chem. Phys., 11, 11387-11400, https://doi.org/10.5194/acp-1111387-2011, 2011.

Gomez-Gonzalez, Y., Surratt, J. D., Cuyckens, F., Szmigielski, R., Vermeylen, R., Jaoui, M., Lewandowski, M., Offenberg, J. H., Kleindienst, T. E., Edney, E. O., Blockhuys, F., Van Alsenoy, C., Maenhaut, W., and Claeys, M.: Characterization of organosulfates from the photooxidation of isoprene and unsaturated fatty acids in ambient aerosol using liquid chromatography/(-) electrospray ionization mass spectrometry, J. Mass. Spectrom., 43, 371-382, https://doi.org/10.1002/jms.1329, 2008.

Gomiscek, B., Hauck, H., Stopper, S., and Preining, O.: Spatial and temporal variations of $\mathrm{PM}_{1}, \mathrm{PM}_{2.5}, \mathrm{PM}_{10}$ and particle number concentration during the AUPHEP-project, Atmos. Environ., 38, 3917-3934, https://doi.org/10.1016/j.atmosenv.2004.03.056, 2004.

Guenther, A., Hewitt, C. N., Erickson, D., Fall, R., Geron, C., Graedel, T., Harley, P., Klinger, L., Lerdau, M., Mckay, W. A., Pierce, T., Scholes, B., Steinbrecher, R., Tallamraju, R., Taylor, J., and Zimmerman, P.: A Global-Model of Natural Volatile Organic-Compound Emissions, J. Geophys. Res., 100, 88738892, https://doi.org/10.1029/94JD02950, 1995.

Guenther, A., Karl, T., Harley, P., Wiedinmyer, C., Palmer, P. I., and Geron, C.: Estimates of global terrestrial isoprene emissions using MEGAN (Model of Emissions of Gases and Aerosols from Nature), Atmos. Chem. Phys., 6, 3181-3210, https://doi.org/10.5194/acp-6-3181-2006, 2006.

Guenther, A. B., Zimmerman, P. R., Harley, P. C., Monson, R. K., and Fall, R.: Isoprene and monoterpene emission rate variability: Model evaluations and sensitivity analyses, J. Geophys. Res., 98, 12609-12617, https://doi.org/10.1029/93JD00527, 1993.

Hakola, H., Tarvainen, V., Laurila, T., Hiltunen, V., Hellen, H., and Keronen, P.: Seasonal variation of VOC concentrations above a boreal coniferous forest, Atmos. Environ., 37, 1623-1634, https://doi.org/10.1016/S1352-2310(03)00014-1, 2003.

Hakola, H., Hellén, H., Hemmilä, M., Rinne, J., and Kulmala, M.: In situ measurements of volatile organic compounds in a boreal forest, Atmos. Chem. Phys., 12, 11665-11678, https://doi.org/10.5194/acp-12-11665-2012, 2012.

Hallquist, M., Wenger, J. C., Baltensperger, U., Rudich, Y., Simpson, D., Claeys, M., Dommen, J., Donahue, N. M., George, C., Goldstein, A. H., Hamilton, J. F., Herrmann, H., Hoffmann, T., Iinuma, Y., Jang, M., Jenkin, M. E., Jimenez, J. L., Kiendler-Scharr, A., Maenhaut, W., McFiggans, G., Mentel, Th. F., Monod, A., Prévôt, A. S. H., Seinfeld, J. H., Surratt, J. D., Szmigielski, R., and Wildt, J.: The formation, properties and impact of secondary organic aerosol: current and emerging issues, Atmos. Chem. Phys., 9, 5155-5236, https://doi.org/10.5194/acp9-5155-2009, 2009.

Hansen, A. M. K., Kristensen, K., Nguyen, Q. T., Zare, A., Cozzi, F., Nøjgaard, J. K., Skov, H., Brandt, J., Christensen, J. H., Ström, J., Tunved, P., Krejci, R., and Glasius, M.: Organosulfates and organic acids in Arctic aerosols: speciation, annual variation and concentration levels, Atmos. Chem. Phys., 14, 7807-7823, https://doi.org/10.5194/acp-14-7807-2014, 2014.

Hansen, A. M. K., Hong, J., Raatikainen, T., Kristensen, K., Ylisirniö, A., Virtanen, A., Petäjä, T., Glasius, M., and Prisle, 
N. L.: Hygroscopic properties and cloud condensation nuclei activation of limonene-derived organosulfates and their mixtures with ammonium sulfate, Atmos. Chem. Phys., 15, 14071-14089, https://doi.org/10.5194/acp-15-14071-2015, 2015.

Hatakeyama, S., Ohno, M., Weng, J. H., Takagi, H., and Akimoto, H.: Mechanism for the Formation of Gaseous and Particulate Products from Ozone-Cycloalkene Reactions in Air, Environ. Sci. Technol., 21, 52-57, https://doi.org/10.1021/Es00155a005, 1987.

Hettiyadura, A. P. S., Stone, E. A., Kundu, S., Baker, Z., Geddes, E., Richards, K., and Humphry, T.: Determination of atmospheric organosulfates using HILIC chromatography with MS detection, Atmos. Meas. Tech., 8, 2347-2358, https://doi.org/10.5194/amt8-2347-2015, 2015.

Hyder, M., Genberg, J., Sandahl, M., Swietlicki, E., and Jönsson, J. A.: Yearly trend of dicarboxylic acids in organic aerosols from south of Sweden and source attribution, Atmos. Environ., 57, 197-204, https://doi.org/10.1016/j.atmosenv.2012.04.027, 2012.

Iinuma, Y., Muller, C., Berndt, T., Boge, O., Claeys, M., and Herrmann, H.: Evidence for the existence of organosulfates from beta-pinene ozonolysis in ambient secondary organic aerosol, Environ. Sci. Technol., 41, 6678-6683, https://doi.org/10.1021/es070938t, 2007.

Ito, K., Xue, N., and Thurston, G.: Spatial variation of PM2.5 chemical species and source-apportioned mass concentrations in New York City, Atmos. Environ., 38, 5269-5282, https://doi.org/10.1016/j.atmosenv.2004.02.063, 2004.

Jung, H. W., Tschaplinski, T. J., Wang, L., Glazebrook, J., and Greenberg, J. T.: Priming in Systemic Plant Immunity, Science, 324, 89-91, https://doi.org/10.1126/science.1170025, 2009.

Kawamura, K. and Gagosian, R. B.: Implications of OmegaOxocarboxylic Acids in the Remote Marine Atmosphere for Photooxidation of Unsaturated Fatty-Acids, Nature, 325, 330-332, https://doi.org/10.1038/325330a0, 1987.

Kawamura, K. and Ikushima, K.: Seasonal-Changes in the Distribution of Dicarboxylic-Acids in the Urban Atmosphere, Environ. Sci. Technol., 27, 2227-2235, doi10.1021/Es00047a033, 1993.

Kawamura, K. and Kaplan, I. R.: Motor Exhaust Emissions as a Primary Source for Dicarboxylic-Acids in LosAngeles Ambient Air, Environ. Sci. Technol., 21, 105-110, https://doi.org/10.1021/Es00155a014, 1987.

Kawamura, K. and Sakaguchi, F.: Molecular distributions of water soluble dicarboxylic acids in marine aerosols over the Pacific Ocean including tropics, J. Geophys. Res., 104, 3501-3509, https://doi.org/10.1029/1998jd100041, 1999.

Kerminen, V. M.: Relative roles of secondary sulfate and organics in atmospheric cloud condensation nuclei production, J. Geophys. Res., 106, 17321-17333, https://doi.org/10.1029/2001jd900204, 2001.

Kristensen, K.: Anthropogenic Enhancement of Biogenic Secondary Organic Aerosols - Investigation of Organosulfates and Dimers of Monoterpene Oxidation Products, PhD thesis, Department of Chemistry and iNano, Aarhus University, Aarhus, Denmark, 2014.

Kristensen, K. and Glasius, M.: Organosulfates and oxidation products from biogenic hydrocarbons in fine aerosols from a forest in North West Europe during spring, Atmos. Environ., 45, 45464556, https://doi.org/10.1016/j.atmosenv.2011.05.063, 2011.
Kristensson, A., Dal Maso, M., Swietlicki, E., Hussein, T., Zhou, J., Kerminen, V. M., and Kulmala, M.: Characterization of new particle formation events at a background site in Southern Sweden: relation to air mass history, Tellus B, 60, 330-344, https://doi.org/10.1111/j.1600-0889.2008.00345.x, 2008.

Kundu, S., Kawamura, K., Andreae, T. W., Hoffer, A., and Andreae, M. O.: Molecular distributions of dicarboxylic acids, ketocarboxylic acids and $\alpha$-dicarbonyls in biomass burning aerosols: implications for photochemical production and degradation in smoke layers, Atmos. Chem. Phys., 10, 2209-2225, https://doi.org/10.5194/acp-10-2209-2010, 2010.

Laothawornkitkul, J., Taylor, J. E., Paul, N. D., and Hewitt, C. N.: Biogenic volatile organic compounds in the Earth system, New Phytol., 183, 27-51, https://doi.org/10.1111/j.14698137.2009.02859.x, 2009.

Ma, Y., Willcox, T. R., Russell, A. T., and Marston, G.: Pinic and pinonic acid formation in the reaction of ozone with alpha-pinene, Chem. Commun., 1328-1330, https://doi.org/10.1039/B617130C, 2007.

Mentel, Th. F., Wildt, J., Kiendler-Scharr, A., Kleist, E., Tillmann, R., Dal Maso, M., Fisseha, R., Hohaus, Th., Spahn, H., Uerlings, R., Wegener, R., Griffiths, P. T., Dinar, E., Rudich, Y., and Wahner, A.: Photochemical production of aerosols from real plant emissions, Atmos. Chem. Phys., 9, 4387-4406, https://doi.org/10.5194/acp-9-4387-2009, 2009.

Mochida, M., Kawabata, A., Kawamura, K., Hatsushika, H., and Yamazaki, K.: Seasonal variation and origins of dicarboxylic acids in the marine atmosphere over the western North Pacific, J. Geophys. Res., 108, 4193, https://doi.org/10.1029/2002JD002355, 2003.

Monson, R. K., Jones, R. T., Rosenstiel, T. N., and Schnitzler, J. P.: Why only some plants emit isoprene, Plant Cell Environ., 36, 503-516, https://doi.org/10.1111/pce.12015, 2013.

Müller, A.: Pimelic acid from salicylic acid, Org. Synth., 11, 42, https://doi.org/10.15227/orgsyn.011.0042, 1931.

Musser, M. T: Adipic Acid, Ullman's Encyclopedia of Industrial Chemistry, https://doi.org/10.1002/14356007.a01_269, 2000.

Nguyen, Q. T., Christensen, M. K., Cozzi, F., Zare, A., Hansen, A. M. K., Kristensen, K., Tulinius, T. E., Madsen, H. H., Christensen, J. H., Brandt, J., Massling, A., Nøjgaard, J. K., and Glasius, M.: Understanding the anthropogenic influence on formation of biogenic secondary organic aerosols in Denmark via analysis of organosulfates and related oxidation products, Atmos. Chem. Phys., 14, 8961-8981, https://doi.org/10.5194/acp14-8961-2014, 2014.

Nyanganyura, D., Maenhaut, W., Mathuthua, M., Makarau, A., and Meixner, F. X.: The chemical composition of tropospheric aerosols and their contributing sources to a continental background site in northern Zimbabwe from 1994 to 2000, Atmos. Environ., 41, 2644-2659, https://doi.org/10.1016/j.atmosenv.2006.11.015, 2007.

Olson, C. N., Galloway, M. M., Yu, G., Hedman, C. J., Lockett, M. R., Yoon, T., Stone, E. A., Smith, L. M., and Keutsch, F. N.: Hydroxycarboxylic Acid-Derived Organosulfates: Synthesis, Stability, and Quantification in Ambient Aerosol, Environ. Sci. Technol., 45, 6468-6474, https://doi.org/10.1021/es201039p, 2011. 
Penuelas, J. and Llusia, J.: BVOCs: plant defense against climate warming?, Trends Plant Sci., 8, 105-109, https://doi.org/10.1016/S1360-1385(03)00008-6, 2003.

Pope, C. A., Thun, M. J., Namboodiri, M. M., Dockery, D. W., Evans, J. S., Speizer, F. E., and Heath, C. W.: Particulate AirPollution as a Predictor of Mortality in a Prospective-Study of US Adults, Am. J. Resp. Crit. Care, 151, 669-674, 1995.

Putaud, J. P., Van Dingenen, R., Alastuey, A., Bauer, H., Birmili, W., Cyrys, J., Flentje, H., Fuzzi, S., Gehrig, R., Hansson, H. C., Harrison, R. M., Herrmann, H., Hitzenberger, R., Huglin, C., Jones, A. M., Kasper-Giebl, A., Kiss, G., Kousa, A., Kuhlbusch, T. A. J., Loschau, G., Maenhaut, W., Molnar, A., Moreno, T., Pekkanen, J., Perrino, C., Pitz, M., Puxbaum, H., Querol, X., Rodriguez, S., Salma, I., Schwarz, J., Smolik, J., Schneider, J., Spindler, G., ten Brink, H., Tursic, J., Viana, M., Wiedensohler, A., and Raes, F.: A European aerosol phenomenology-3: Physical and chemical characteristics of particulate matter from 60 rural, urban, and kerbside sites across Europe, Atmos. Environ., 44, 1308-1320, https://doi.org/10.1016/j.atmosenv.2009.12.011, 2010.

Räisänen, T., Ryyppö, A., and Kellomäki, S.: Effects of elevated $\mathrm{CO}_{2}$ and temperature on monoterpene emission of Scots pine (Pinus sylvestris L.), Atmos. Environ., 42, 4160-4171, https://doi.org/10.1016/j.atmosenv.2008.01.023, 2008.

Riva, M., Tomaz, S., Cui, T. Q., Lin, Y. H., Perraudin, E., Gold, A., Stone, E. A., Villenave, E., and Surratt, J. D.: Evidence for an Unrecognized Secondary Anthropogenic Source of Organosulfates and Sulfonates: Gas-Phase Oxidation of Polycyclic Aromatic Hydrocarbons in the Presence of Sulfate Aerosol, Environ. Sci. Technol., 49, 6654-6664, https://doi.org/10.1021/acs.est.5b00836, 2015.

Riva, M., Da Silva Barbosa, T., Lin, Y.-H., Stone, E. A., Gold, A., and Surratt, J. D.: Chemical characterization of organosulfates in secondary organic aerosol derived from the photooxidation of alkanes, Atmos. Chem. Phys., 16, 11001-11018, https://doi.org/10.5194/acp-16-11001-2016, 2016.

Schindelka, J., Iinuma, Y., Hoffmann, D., and Herrmann, H.: Sulfate radical-initiated formation of isoprene-derived organosulfates in atmospheric aerosols, Faraday Discuss., 165, 237-259, https://doi.org/10.1039/c3fd00042g, 2013.

Seibert, P. and Frank, A.: Source-receptor matrix calculation with a Lagrangian particle dispersion model in backward mode, Atmos. Chem. Phys., 4, 51-63, https://doi.org/10.5194/acp-4-512004, 2004.

Shalamzari, M. S., Ryabtsova, O., Kahnt, A., Vermeylen, R., Herent, M. F., Quetin-Leclercq, J., Van der Veken, P., Maenhaut, W., and Claeys, M.: Mass spectrometric characterization of organosulfates related to secondary organic aerosol from isoprene, Rapid Commun. Mass Sp., 27, 784-794, https://doi.org/10.1002/rcm.6511, 2013.

Sharkey, T. D., Wiberley, A. E., and Donohue, A. R.: Isoprene emission from plants: Why and how, Ann. Bot.-London, 101, 5-18, https://doi.org/10.1093/aob/mcm240, 2008.

Stein, A. F., Draxler, R. R., Rolph, G. D., Stunder, B. J. B., Cohen, M. D., and Ngan, F.: Noaa's Hysplit Atmospheric Transport and Dispersion Modeling System, B. Am. Meteorol. Soc., 96, 20592077, https://doi.org/10.1175/Bams-D-14-00110.1, 2015.

Steinbrecher, R., Hauff, K., Hakola, H., and Rössler, J.: A revised parameterisation for emission modelling of isoprenoids for bo- real plants, The European Commission, Luxembourg, 29-43, 1999.

Stephanou, E. G. and Stratigakis, N.: Oxocarboxylic and Alpha,Omega-Dicarboxylic Acids - Photooxidation Products of Biogenic Unsaturated Fatty-Acids Present in Urban Aerosols, Environ. Sci. Technol., 27, 1403-1407, https://doi.org/10.1021/Es00044a016, 1993.

Stohl, A., Forster, C., Frank, A., Seibert, P., and Wotawa, G.: Technical note: The Lagrangian particle dispersion model FLEXPART version 6.2, Atmos. Chem. Phys., 5, 2461-2474, https://doi.org/10.5194/acp-5-2461-2005, 2005.

Surratt, J. D., Kroll, J. H., Kleindienst, T. E., Edney, E. O., Claeys, M., Sorooshian, A., Ng, N. L., Offenberg, J. H., Lewandowski, M., Jaoui, M., Flagan, R. C., and Seinfeld, J. H.: Evidence for organosulfates in secondary organic aerosol, Environ. Sci. Technol., 41, 517-527, https://doi.org/10.1021/es062081q, 2007a.

Surratt, J. D., Lewandowski, M., Offenberg, J. H., Jaoui, M., Kleindienst, T. E., Edney, E. O., and Seinfeld, J. H.: Effect of acidity on secondary organic aerosol formation from isoprene, Environ. Sci. Technol., 41, 5363-5369, https://doi.org/10.1021/es0704176, 2007b.

Surratt, J. D., Gomez-Gonzalez, Y., Chan, A. W. H., Vermeylen, R., Shahgholi, M., Kleindienst, T. E., Edney, E. O., Offenberg, J. H., Lewandowski, M., Jaoui, M., Maenhaut, W., Claeys, M., Flagan, R. C., and Seinfeld, J. H.: Organosulfate formation in biogenic secondary organic aerosol, J. Phys. Chem. A, 112, 8345-8378, https://doi.org/10.1021/jp802310p, 2008.

Surratt, J. D., Chan, A. W. H., Eddingsaas, N. C., Chan, M. N., Loza, C. L., Kwan, A. J., Hersey, S. P., Flagan, R. C., Wennberg, P. O., and Seinfeld, J. H.: Reactive intermediates revealed in secondary organic aerosol formation from isoprene, P. Natl. Acad. Sci. USA, 107, 6640-6645, https://doi.org/10.1073/pnas.0911114107, 2010.

Szmigielski, R., Surratt, J. D., Gomez-Gonzalez, Y., Van der Veken, P., Kourtchev, I., Vermeylen, R., Blockhuys, F., Jaoui, M., Kleindienst, T. E., Lewandowski, M., Offenberg, J. H., Edney, E. O., Seinfeld, J. H., Maenhaut, W., and Claeys, M.: 3-methyl1,2,3-butanetricarboxylic acid: An atmospheric tracer for terpene secondary organic aerosol, Geophys. Res. Lett., 34, L24811, https://doi.org/10.1029/2007GL031338, 2007.

Tolocka, M. P. and Turpin, B.: Contribution of Organosulfur Compounds to Organic Aerosol Mass, Environ. Sci. Technol., 46, 7978-7983, https://doi.org/10.1021/es300651v, 2012.

van Pinxteren, D., Brüggemann, E., Gnauk, T., Müller, K., Thiel, C., and Herrmann, H.: A GIS based approach to back trajectory analysis for the source apportionment of aerosol constituents and its first application, J. Atmos. Chem., 67, 1-28, https://doi.org/10.1007/s10874-011-9199-9, 2010.

van Pinxteren, D., Neusüß, C., and Herrmann, H.: On the abundance and source contributions of dicarboxylic acids in size-resolved aerosol particles at continental sites in central Europe, Atmos. Chem. Phys., 14, 3913-3928, https://doi.org/10.5194/acp-143913-2014, 2014.

Wehner, B. and Wiedensohler, A.: Long term measurements of submicrometer urban aerosols: statistical analysis for correlations with meteorological conditions and trace gases, Atmos. Chem. Phys., 3, 867-879, https://doi.org/10.5194/acp-3-8672003, 2003. 
Viana, M., Querol, X., Alastuey, A., Gil, J. I., and Menendez, M.: Identification of PM sources by principal component analysis (PCA) coupled with wind direction data, Chemosphere, 65, 2411-2418, https://doi.org/10.1016/j.chemosphere.2006.04.060, 2006.

Yttri, K. E., Simpson, D., Nøjgaard, J. K., Kristensen, K., Genberg, J., Stenström, K., Swietlicki, E., Hillamo, R., Aurela, M., Bauer, H., Offenberg, J. H., Jaoui, M., Dye, C., Eckhardt, S., Burkhart, J. F., Stohl, A., and Glasius, M.: Source apportionment of the summer time carbonaceous aerosol at Nordic rural background sites, Atmos. Chem. Phys., 11, 13339-13357, https://doi.org/10.5194/acp-11-13339-2011, 2011.
Zhang, R. Y., Wang, L., Khalizov, A. F., Zhao, J., Zheng, J., McGraw, R. L., and Molina, L. T.: Formation of nanoparticles of blue haze enhanced by anthropogenic pollution, P. Natl. Acad. Sci. USA, 106, 17650-17654, https://doi.org/10.1073/pnas.0910125106, 2009.

Zhang, Y. Y., Müller, L., Winterhalter, R., Moortgat, G. K., Hoffmann, T., and Pöschl, U.: Seasonal cycle and temperature dependence of pinene oxidation products, dicarboxylic acids and nitrophenols in fine and coarse air particulate matter, Atmos. Chem. Phys., 10, 7859-7873, https://doi.org/10.5194/acp-107859-2010, 2010. 